\title{
Classification of Regions of Ukraine by the Level of Social Tension
}

\author{
TAMARA KLEBANOVA \\ Economic Cybernetics Department \\ Simon Kuznets Kharkiv National University of Economics \\ 9-A, Nauki Ave., Kharkiv, 61116 \\ UKRAINE \\ OLHA RUDACHENKO \\ Department of Entrepreneurship and Business Administration \\ O.M. Beketov National University of Urban Economy in Kharkiv \\ 17, Marshal Bazhanov Street, Kharkiv, 61002 \\ UKRAINE \\ VITALII GVOZDYTSKYI \\ Economic Cybernetics Department \\ Simon Kuznets Kharkiv National University of Economics \\ 9-A, Nauki Ave., Kharkiv, 61116 \\ UKRAINE \\ MOZGOVYI IEVGEN \\ Department of Entrepreneurship and Business Administration \\ O.M. Beketov National University of Urban Economy in Kharkiv \\ 17, Marshal Bazhanov Street, Kharkiv, 61002 \\ UKRAINE \\ LIDIYA GURYANOVA \\ Economic Cybernetics Department \\ Simon Kuznets Kharkiv National University of Economics \\ 9-A, Nauki Ave., Kharkiv, 61116 \\ UKRAINE
}

\begin{abstract}
The analysis of indicators that reflect changes in the social, economic and political spheres in recent years has shown their significant deterioration and the possibility of growing social tensions in the regions of Ukraine. The purpose of the study is to classify the regions of Ukraine according to the level of formation of social tensions and to determine anticipative measures aimed at preventing the creation of crisis situations.

The article proposes a methodical approach to the classification of regions using the methods of cluster, discriminant analysis and analysis of variance according to the level of social tension, which includes two main stages: substantiation of the system of socio-economic indicators characterizing the level of social tension; selection and substantiation of models of classification of the regions.

Within the first stage of the methodical approach the system of indicators which reflect changes in social, economic and political spheres of Ukraine in modern transformational conditions was constructed.

Within the framework of the second stage of the methodical approach on the basis of cluster analysis the classification of regions according to the level of formation of social tension was carried out. The classes of regions were selected: with a low level of formation of social tension; with an intensified level of formation of social tension; with a high level of formation of social tension.

The results of the study showed that the number of regions in the class with a high level of social tension is constantly growing and, unfortunately, the number of regions with high socio-economic development is decreasing. The classification of regions made it possible to determine the list of preventive measures that can reduce the losses of the state associated with the containment of possible crises in the social sphere. However, the article also states that such a list of activities should take into account the specifics of the region that is part of each class.
\end{abstract}

Key-Words: crisis, cluster analysis, economic and mathematical models, region, social tension, transformation 


\section{Introduction}

The analysis of socio-economic indicators of development of Ukraine's regions showed a significant deterioration in the social sphere: constant migration of the unemployed, wage arrears, huge losses of enterprises, increased utility bills - all this leads to increasing social tensions (ST). This exacerbates the problem of preventing social tensions, which in the future may lead to a social crisis not only in the region but also in the country as a whole. That is why it is of great interest to identify regions that are characterized by rapid growth of ST that can lead to the weakening of national security.

Modern tools of economic and mathematical models associated with the study of social tensions, including different methods of cluster analysis, provide an opportunity to cope with the task of identifying regions in which crisis situations are presented. Such regions need special attention from the Government, which will allow to form preventive management decisions aimed at maintaining the appropriate standard of life activity of the regions and the country as a whole.

\section{Problem Formulation}

\subsection{Literature review}

Social and economic development of the region of the country has been dedicated to a lot of studies and researches. So the works of the authors L. Guryanova and L. Chagovets (2019) are devoted to the construction of models for assessing and forecasting the economic development of the regions of Ukraine $[6,18,21]$; the concept of social tension and its conceptualization as a socio-psychological phenomenon was revealed in the works of O. Zlobina (2019) [24]; types of social tensions that arise at the meso level in organizations within the sociological, psychological and integrated approaches are presented by L. Karamushka (2016) [9]; development of an integrated indicator for assessing the level of social tension in the regions of the country on the basis of objective statistical information is presented in the work of Andrenko O. (2015) [1]; Babenko V. (2020) analyzed the modern processes of regional integration in the framework of sustainable economic development [20].
Analyzing the results of scientific research on the problems of social tension, which affects the sustainable development of regions, it is worth noting the work of such researchers as: Marinovic M., Glaría A., Marinovic D. (2018) who applied a systemic approach and the Systemic Management Model which shows how a social destabilizing process and critical collapse in both politics, economy and society generate the breakdown of the democratic institutions [13]; Janssen L., Kullberg M-L., Verkuil B, van Zwieten N, Wever M., van Houtum L., et al. (2020), who performed a multilevel analysis of a social tension at the social micro level (families) in the basis of the consequences of COVID-19 pandemic [7]; T. S. Klebanova (2009) was engaged in construction of models of strengthening of social tension considering a factor of unevenness of regional development [10-11].

The works of foreign scientists also deserve great attention: T. Hobbes, E. Durkheim, R. Merton, A. Murray, R. Darendorf, T. Parsons, R. Selye, Xiaohua D. and others.

However, little attention has been paid to the problems associated with the development of models of preventive management, which are aimed at identifying regions with a high level of social tension which lead to a decrease in the pace of economic development of both individual regions and the country as a whole.

Thus, the purpose of this study is to classify the regions of Ukraine according to the level of formation of social tensions and to determine preventive measures aimed at preventing the creation of crisis situations.

\subsection{Research methods}

The current stage of socio-economic development of many countries, including Ukraine as was mentioned above, is characterized by a sufficient increasing of the level of social tension [2-3, 5, 15, 17-18, 20]. This leads to a sharp change in political attitudes and expectations in society, the global restoration of the institutional and political environment, increasing turbulence in all socio-economic subsystems, a sharp decline in national security. The current situation indicates the need to transform and improve systems for monitoring the level of social tension based on the use of modern economic and mathematical methods 
and information technologies of data analysis. Such models primarily include models for classifying multidimensional objects and processes based on cluster analysis (Ward's method, agglomerative and divisional methods, K-means method and fuzzy classification methods).

The authors believe that social tensions for most emerging economies arise both at the level of society and at the level of social groups caused by the confrontation between the need for stability and reform. Stability requires the adoption of rules and ideals by society, and reforming adaptation to new conditions. In this case, the tension is associated with a collective desire to increase welfare. For European countries with a high level of socio-economic development, this approach is correct, and for countries with a lower level of development, which are difficult to eliminate the negative effects of rising tensions, first of all, it is necessary to assess the relationship of social and economic factors [16].

It should be noted that the socio-economic situation, which is typical for Ukraine, where under the influence of the transformations carried out at that time, has significantly deteriorated. This is evidenced by the decline in a large number of international indicators that characterize the stability of the country's development. Thus, the Indicator of Economic Sentiment (IES) in Ukraine, calculated by the State Statistics Service, in the first quarter of 2020 amounted to $103 \%$ compared to the fourth quarter of 2019 , from $113.4 \%$, indicating a significant decline.

Below is a histogram of gross regional product (GRP) by region of Ukraine in the period from 2016 to 2019 .

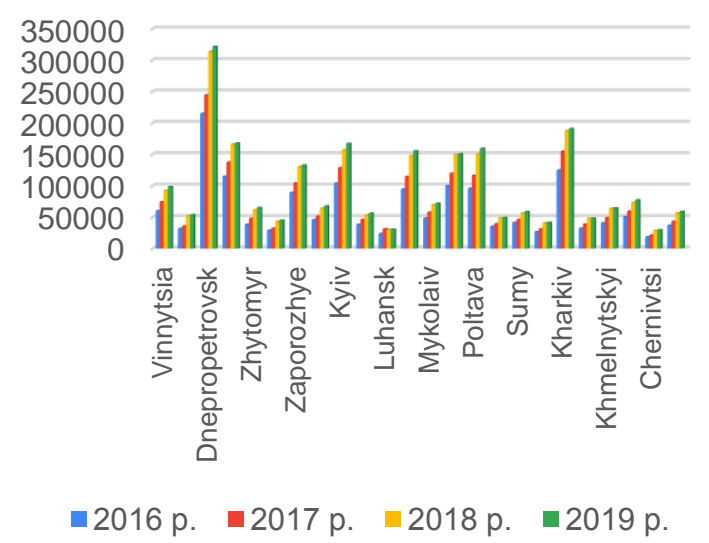

Fig. 1. Dynamics of GRP change by regions of Ukraine in the period from 2016 to 2019.

Source: built by the authors on the basis of the State Statistics Service of Ukraine [8].

As can be seen from the histogram, most regions of Ukraine are characterized by a decline in gross regional product. Also, according to the State Statistics Service of Ukraine, there was a decline in all four indicators of business confidence: components of IES: in construction (from $-18.9 \%$ in the fourth quarter of 2019 to $-21.7 \%$ ), in processing industry (from $-5.5 \%$ to $-6.4 \%$ ), in services (from + $1.6 \%$ to $-3 \%$ ) and in retail trade (from $+13.7 \%$ to + $3.7 \%)$. In addition, the consumer confidence indicator fell (from $-5.8 \%$ to $-11.4 \%$ ). In general, the growth of gross domestic product in the IV quarter of 2019 slowed to $1.5 \%$ [8]. Thus, above analysis indicates a deterioration of socio-economic indicators and the possibility of increasing social tensions in the regions of Ukraine

The methodical approach of classification of regions on a level of formation of social tension offered in work includes 2 basic stages:

1 Stage. Substantiation of the system of socioeconomic indicators that characterize the level of social tension.

2 Stage. Selection and substantiation of models of classification of the regions.

Based on the analysis of literary sources $[2-3,5$, $9,16,18]$, as well as the Recommendations approved by the Resolution of the Cabinet of Ministers of Ukraine, a system of indicators that reflect changes in the social, economic and political spheres was built (Table 1).

Table 1 - Systems of indicators for assessing the social tension of regions

\begin{tabular}{|l|c|}
\hline \multicolumn{1}{|c|}{ Indicator } & Symbol \\
\hline Gross regional product, UAH mln & $\mathrm{x}_{1}$ \\
\hline $\begin{array}{l}\text { Unemployed population } \\
\text { (according to the ILO } \\
\text { methodology) (in \% to the labor } \\
\text { force of the corresponding age) }\end{array}$ & $\mathrm{x}_{2}$ \\
\hline $\begin{array}{l}\text { Average monthly salary by regions } \\
\text { for the period from the beginning } \\
\text { of the year, UAH }\end{array}$ & $\mathrm{x}_{3}$ \\
\hline $\begin{array}{l}\text { Amount of arrears of wages, UAH } \\
\text { mln }\end{array}$ & $\mathrm{x}_{4}$ \\
\hline $\begin{array}{l}\text { Volume of sold industrial products } \\
\text { by regions, UAH mln }\end{array}$ & $\mathrm{x}_{5}$ \\
\hline Retail trade turnover, UAH mln & $\mathrm{x}_{6}$ \\
\hline $\begin{array}{l}\text { Capital investments by regions, } \\
\text { UAH mln. }\end{array}$ & $\mathrm{x}_{7}$ \\
\hline Freight turnover, mln tkm & $\mathrm{x}_{8}$ \\
\hline $\begin{array}{l}\text { Passenger turnover, mln passenger } \\
\text { km }\end{array}$ & $\mathrm{x}_{9}$ \\
\hline Exports, thousand US dollars & $\mathrm{x}_{10}$ \\
\hline Imports, thousand US dollars & $\mathrm{x}_{11}$ \\
\hline Balance, thousand US dollars & $\mathrm{x}_{12}$ \\
\hline
\end{tabular}


Continuation of Table 1

\begin{tabular}{|l|c|}
\hline \multicolumn{1}{|c|}{ Indicator } & Symbol \\
\hline $\begin{array}{l}\text { Number of enterprises by their size } \\
\text { by region, pieces }\end{array}$ & $\mathrm{x}_{13}$ \\
\hline $\begin{array}{l}\text { Debt of the population for housing } \\
\text { and communal services, thousand } \\
\text { UAH }\end{array}$ & $\mathrm{x}_{14}$ \\
\hline $\begin{array}{l}\text { The total amount of subsidies } \\
\text { allocated to households to } \\
\text { reimburse the cost of housing, } \\
\text { thousand UAH }\end{array}$ & $\mathrm{x}_{15}$ \\
\hline Number of arrivals, pers. & $\mathrm{x}_{16}$ \\
\hline Number of retirees, pers. & $\mathrm{x}_{17}$ \\
\hline Migration growth, reduction (-) & $\mathrm{x}_{18}$ \\
\hline
\end{tabular}

Source: built by the authors

Change of the values of the indicators listed in Table 1 may lead to an increase in social tensions in the regions of the country. Thus, the fall in average monthly wages by region and the growth of the unemployed and the amount of arrears of wages, lead to huge arrears of housing and communal services, which, in turn, has a significant impact on the socioeconomic development of the country. The constant migration of the population is determined by a serious problem on the way to preserving and developing the country's labor potential.

Then, in the second stage, using the methods of cluster, discriminant analysis and analysis of variance, the choice of models for the classification of regions according to the level of formation of social tension was made.

The application of cluster analysis methods is justified by the fact that they allow to solve the following problems $[4,10,12,14,23]$ :

- to classify objects taking into account the features that reflect the nature of objects;

- to check the assumptions about the presence of a certain structure in the studied set of objects;

- to build a new classification for little-studied phenomena, when it is necessary to establish the presence of connections within the population.

Cluster methods place objects studied in groups that can differ significantly in composition and quality of partitioning.

Verification of the system of socio-economic indicators (Table 1) was carried out using analysis of variance. It showed that indicators such as "Wage arrears", "Freight turnover", "Passenger turnover", "Subsidies", "Number of arrivals" and "Number of retirees " can be excluded due to the low variability of the variance (Fig. 2).

\begin{tabular}{|c|c|c|c|c|c|c|}
\hline \multirow[b]{2}{*}{ Variable } & \multicolumn{6}{|c|}{ Analysis of Variance (Initial data 2015) } \\
\hline & $\begin{array}{l}\text { Between } \\
\text { SS }\end{array}$ & df & $\begin{array}{c}\text { Within } \\
\text { SS }\end{array}$ & df & $\mathrm{F}$ & $\begin{array}{c}\text { signif. } \\
p\end{array}$ \\
\hline GRP & $3,039449 E+10$ & 2 & $1,726036 \mathrm{E}+10$ & 21 & 18,48989 & 0,000023 \\
\hline Unemployment & $7,073118 \mathrm{E}+03$ & 2 & $3,958011 \mathrm{E}+03$ & 21 & 18,76390 & 0,000021 \\
\hline Salary & $3,992749 E+06$ & 2 & $1,049891 E+06$ & 21 & 39,93165 & 0,000000 \\
\hline Salary debts & $4,402016 E+04$ & 2 & $1,832091 E+05$ & 21 & 2,52286 & 0,104248 \\
\hline Volume Industr & $7,265155 \mathrm{E}+10$ & 2 & $2,188068 \mathrm{E}+10$ & 21 & 34,86370 & 0,000000 \\
\hline Volume Retail & $4,744462 E+09$ & 2 & $5,966366 \mathrm{E}+09$ & 21 & 8,34961 & 0,002147 \\
\hline Capital investments & $3,216108 E+08$ & 2 & $5,378132 \mathrm{E}+08$ & 21 & 6,27897 & 0,007285 \\
\hline Cargo turnover & $6,470002 E+08$ & 2 & $4,733808 \mathrm{E}+09$ & 21 & 1,43510 & 0,260503 \\
\hline Passengers & $7,666896 \mathrm{E}+06$ & 2 & $1,216667 \mathrm{E}+08$ & 21 & 0,66166 & 0,526422 \\
\hline Export & $3,841030 E+13$ & 2 & $7,461033 \mathrm{E}+12$ & 21 & 54,05526 & 0,000000 \\
\hline Import & $8,439542 E+12$ & 2 & $5,748899 \mathrm{E}+12$ & 21 & 15,41429 & 0,000076 \\
\hline Saldo & $1,430052 E+13$ & 2 & $3,858287 \mathrm{E}+12$ & 21 & 38,91766 & 0,000000 \\
\hline Enterprises QTY & $6,068290 E+08$ & 2 & $4,910909 \mathrm{E}+08$ & 21 & 12,97459 & 0,000214 \\
\hline Debts for Communal services & $1,419671 \mathrm{E}+13$ & 2 & $3,849941 \mathrm{E}+12$ & 21 & 38,71888 & 0,000000 \\
\hline Subsidies & $6.406383 \mathrm{E}+08$ & 2 & $4,871009 \mathrm{E}+10$ & 21 & 0,13810 & 0,871799 \\
\hline Arrived, QTY & $3,725092 \mathrm{E}+08$ & 2 & $1,510460 \mathrm{E}+09$ & 21 & 2,58951 & 0,098808 \\
\hline Departed, QTY & $3,295500 \mathrm{E}+08$ & 2 & $1,018851 E+09$ & 21 & 3,39625 & 0,052731 \\
\hline Migration & $9,235147 \mathrm{E}+07$ & 2 & $1,935043 \mathrm{E}+08$ & 21 & 5,01121 & 0,016623 \\
\hline
\end{tabular}

Fig. 2. Analysis of variance

Source: built by the authors

Thus, for cluster analysis, a matrix of initial data was formed on the basis of the State Statistics Service of Ukraine for the period from 2016 to 2018, previously considered 12 indicators for 24 regions of Ukraine [8]. The calculations were performed using Statistica software package.

\section{Problem Solution}

For further analysis, it is interesting to visualize the structure of the relationship between the regions. For this purpose, a hierarchical classification was used the Ward method. Constructed dendrogram by the method of Ward is shown on Fig. 3.

Tree Diagram for 24 Cases

Ward's method

Euclidean distances

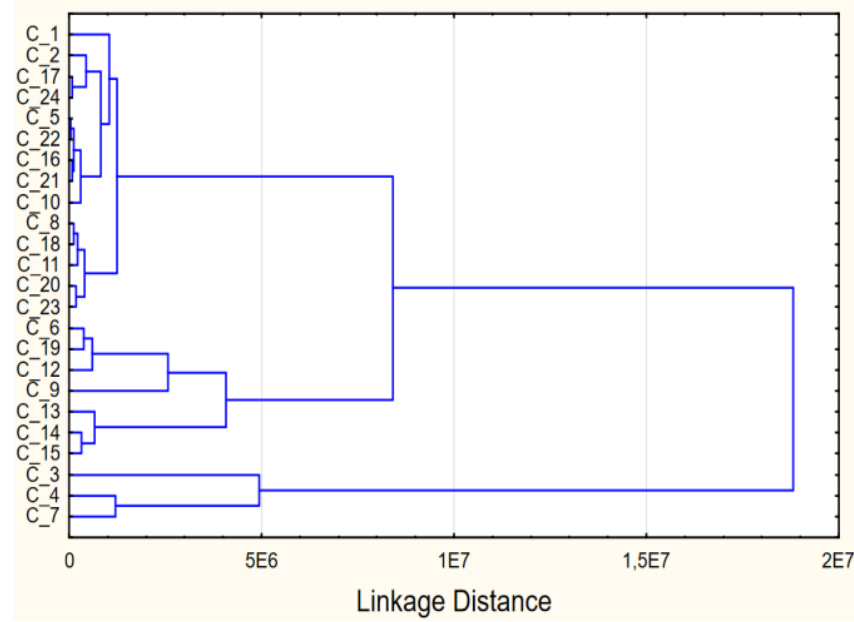

Fig. 3. Dendrogram by the method of Ward

Source: built by the authors

As can be seen from Fig. 3, the obtained dendrogam allows to form a hypothesis about the existence of 2 and 3 clusters for the studied population according to the level of formation of 
social tension. Verification of this number of clusters was based on the iterative method of k-means.

The method used made it possible to conclude that the division into 3 clusters is optimal. Fig. 4 shows the changes in the mean of the indicators in each cluster.

\begin{tabular}{|l|r|r|r|}
\hline \multirow{2}{*}{ Variable } & \multicolumn{3}{|c|}{ Cluster Means (Initial data 2015) } \\
\cline { 2 - 4 } & \multicolumn{1}{c|}{$\begin{array}{c}\text { Cluster } \\
\text { No. 1 }\end{array}$} & $\begin{array}{c}\text { Cluster } \\
\text { No. 2 }\end{array}$ & $\begin{array}{c}\text { Cluster } \\
\text { No. 3 }\end{array}$ \\
\hline GRP & 37230,5 & 139760 & 85191 \\
\hline Unemployment & 53,2 & 106 & 70 \\
\hline Salary & 3305,9 & 4518 & 3791 \\
\hline Volume Industr & 25380,0 & 196746 & 60102 \\
\hline Volume Retail & 24148,7 & 58108 & 49693 \\
\hline Capital investments & 4705,5 & 14006 & 11012 \\
\hline Export & 426229,5 & 4341776 & 1444908 \\
\hline Import & 271815,7 & 1837781 & 1241135 \\
\hline Saldo & 154413,9 & 2503995 & 203772 \\
\hline Enterprises QTY & 6442,0 & 17812 & 16062 \\
\hline Debts for Communal services & 147971,9 & 2486183 & 187710 \\
\hline Migration & $-422,4$ & -3796 & 2582 \\
\hline
\end{tabular}

Fig. 4. Mean values of each indicator in individual clusters

Source: built by the authors

Checking for cluster separation is confirmed by the found values of Euclidean distances presented on Fig. 5.

\begin{tabular}{|l|r|r|r|}
\hline \multirow{4}{*}{$\begin{array}{l}\text { Cluster } \\
\text { Number }\end{array}$} & \multicolumn{3}{|l|}{$\begin{array}{l}\text { Euclidean Distances between Clusters (Initial data 2015) } \\
\text { Distances below diagonal } \\
\text { Squared distances above diagonal }\end{array}$} \\
\cline { 2 - 4 } & No.1 & No. 2 & No. 3 \\
\hline No.1 & 0 & $2,401064 \mathrm{E}+12$ & $1,654668 \mathrm{E}+11$ \\
\hline No. 2 & 1549537 & $0,000000 \mathrm{E}-01$ & $1,611967 \mathrm{E}+12$ \\
\hline No. 3 & 406776 & $1,269633 \mathrm{E}+06$ & $0,000000 \mathrm{E}-01$ \\
\hline
\end{tabular}

Fig. 5. Matrix of Euclidean distances between clusters

Source: built by the authors

As can be seen from Fig. 5, the clusters are well separated and can be considered for further study.

Thus, Fig. 6 presents descriptive statistics for the first cluster.

\begin{tabular}{|l|r|r|r|}
\hline \multirow{2}{*}{ Variable } & \multicolumn{3}{|c|}{ Descriptive Statistics for Cluster 1 (Initial data 2015) } \\
& Cluster contains 14 cases \\
\cline { 2 - 4 } & Mean & $\begin{array}{c}\text { Standard } \\
\text { Deviation }\end{array}$ & Variance \\
\hline GRP & 37230,5 & 10778,2 & $1,161692 \mathrm{E}+08$ \\
\hline Unemployment & 53,2 & 7,4 & $5,407341 \mathrm{E}+01$ \\
\hline Salary & 3305,9 & 159,4 & $2,542376 \mathrm{E}+04$ \\
\hline Volume Industr & 25380,0 & 10764,0 & $1,158629 \mathrm{E}+08$ \\
\hline Volume Retail & 24148,7 & 6715,1 & $4,509290 \mathrm{E}+07$ \\
\hline Capital investments & 4705,5 & 2060,3 & $4,244951 \mathrm{E}+06$ \\
\hline Export & 426229,5 & 187458,4 & $3,514066 \mathrm{E}+10$ \\
\hline Import & 271815,7 & 137111,2 & $1,879947 \mathrm{E}+10$ \\
\hline Saldo & 154413,9 & 156207,9 & $2,440090 \mathrm{E}+10$ \\
\hline Enterprises QTY & 6442,0 & 1725,9 & $2,978802 \mathrm{E}+06$ \\
\hline Debts for Communal services & 147971,9 & 154962,1 & $2,401324 \mathrm{E}+10$ \\
\hline Migration & $-422,4$ & 1715,3 & $2,942229 \mathrm{E}+06$ \\
\hline
\end{tabular}

Fig. 6. Descriptive statistics of 1 cluster

Source: built by the authors

The elements of the 1st cluster included: Vinnytsia, Volyn, Zhytomyr, Ivano-Frankivsk, Kirovohrad, Luhansk, Rivne, Sumy, Ternopil,
Kherson, Khmelnytsky, Cherkasy, Chernivtsi, Chernihiv regions.

Below is a descriptive statistics for another cluster (Fig. 7).

\begin{tabular}{|l|r|r|r|}
\hline \multirow{2}{*}{ Variable } & \multicolumn{3}{|l|}{$\begin{array}{l}\text { Descriptive Statistics for Cluster 2 (Initial data 2015) } \\
\text { Cluster contains 3 cases }\end{array}$} \\
\cline { 2 - 5 } & Mean & $\begin{array}{c}\text { Standard } \\
\text { Deviation }\end{array}$ & Variance \\
\hline GRP & \multicolumn{3}{|c|}{} \\
\hline Unemployment & 106 & 66614 & $4,437475 \mathrm{E}+09$ \\
\hline Salary & 4518 & 22 & $4,893700 \mathrm{E}+02$ \\
\hline Volume Industr & 196746 & 82428 & $6,794440 \mathrm{E}+09$ \\
\hline Volume Retail & 58108 & 33174 & $1,100546 \mathrm{E}+09$ \\
\hline Capital investments & 14006 & 10321 & $1,065177 \mathrm{E}+08$ \\
\hline Export & 4341776 & 1822112 & $3,320092 \mathrm{E}+12$ \\
\hline Import & 1837781 & 1203016 & $1,447255 \mathrm{E}+12$ \\
\hline Saldo & 2503995 & 664142 & $4,410851 \mathrm{E}+11$ \\
\hline Enterprises QTY & 17812 & 8282 & $6,858522 \mathrm{E}+07$ \\
\hline Debts for Communal services & 2486183 & 657672 & $4,325325 \mathrm{E}+11$ \\
\hline Migration & -3796 & 4722 & $2,229914 \mathrm{E}+07$ \\
\hline
\end{tabular}

Fig. 7. Descriptive statistics of 2 cluster

Source: built by the authors

The elements of the 2nd cluster included: Dnipropetrovsk, Donetsk and Zaporizhia regions.

Below is a descriptive statistics for 3 cluster (Fig. 8).

\begin{tabular}{|l|r|r|r|}
\hline \multirow{2}{*}{ Variable } & \multicolumn{3}{|c|}{$\begin{array}{l}\text { Descriptive Statistics for Cluster 3 (Initial data 2015) } \\
\text { Cluster contains 7 cases }\end{array}$} \\
\cline { 2 - 4 } & Mean & $\begin{array}{l}\text { Standard } \\
\text { Deviation }\end{array}$ & Variance \\
\hline GRP & 85191 & 33850,7 & $1,145869 \mathrm{E}+09$ \\
\hline Unemployment & 70 & 19,5 & $3,793862 \mathrm{E}+02$ \\
\hline Salary & 3791 & 250,5 & $6,273881 \mathrm{E}+04$ \\
\hline Volume Industr & 60102 & 33629,3 & $1,130930 \mathrm{E}+09$ \\
\hline Volume Retail & 49693 & 23018,4 & $5,298444 \mathrm{E}+08$ \\
\hline Capital investments & 11012 & 6703,2 & $4,493225 \mathrm{E}+07$ \\
\hline Export & 1444908 & 246312,8 & $6,066997 \mathrm{E}+10$ \\
\hline Import & 1241135 & 659544,8 & $4,349994 \mathrm{E}+11$ \\
\hline Saldo & 203772 & 665695,8 & $4,431508 \mathrm{E}+11$ \\
\hline Enterprises QTY & 16062 & 7247,9 & $5,253267 \mathrm{E}+07$ \\
\hline Debts for Communal services & 187710 & 667421,0 & $4,454508 \mathrm{E}+11$ \\
\hline Migration & 2582 & 4294,5 & $1,844283 \mathrm{E}+07$ \\
\hline
\end{tabular}

Fig. 8. Descriptive statistics of 3 cluster

Source: built by the authors

The elements of the 3rd cluster included: Zakarpattia, Lviv, Mykolaiv, Odesa, Poltava, Kharkiv regions and Kyiv region (excluding Kyiv city).

Thus, the analysis of the values of socio-economic indicators of each cluster allowed to identify the following classes of regions according to the level of formation of social tension:

Class 1 - characterized by a low level of social tension, which characterizes serious changes in living conditions that lead to a significant reduction in the level of socio-economic development of the country;

Class 2 - characterized by a low level of formation of social tension, which characterizes the balance of conditions and requirements associated with the growth of socio-economic development of the country; 
Class 3 - characterized by a high level of social tension, which characterizes the emergence of a large number of contradictions, the imbalance of which leads to crises not only in the region but also in the country as a whole.

The above characteristics of each class make it possible to determine their names, which are shown in Table 2.

The characteristics of each class are given below in Table 2.

Table 2 - Classes of regions according to the level of formation of social tension

\begin{tabular}{|c|c|}
\hline $\begin{array}{c}\text { No. of } \\
\text { class }\end{array}$ & Class \\
\hline 1 & Intensified level of social tension \\
\hline 2 & Low level of social tension \\
\hline 3 & High level of social tension \\
\hline
\end{tabular}

Source: compiled by the authors

The 3rd class with a high level of social tension which leads to a crise has the biggest interest for studying. Regions which which are in this class must have strong state support from the government in the social sphere.

A similar study related to the classification of regions was conducted according to the proposed system of indicators for 2016-2019. Their compared results for 2016 are presented on Table 3.

Table 3 - Summary of the classification of regions by level of social tension for 2016-2019

\begin{tabular}{|c|c|c|c|c|c|}
\hline Region & 2016 & 2017 & 2018 & 2019 & $\begin{array}{c}\text { General } \\
\text { conso- } \\
\text { lidated } \\
\text { indica- } \\
\text { tor }\end{array}$ \\
\hline Vinnytsia & High & High & High & High & High \\
\hline Volyn & High & $\begin{array}{c}\text { Intensi- } \\
\text { fied }\end{array}$ & High & High & High \\
\hline Dnipro & Low & Low & Low & Low & Low \\
\hline Donetsk & Low & Low & Low & Low & Low \\
\hline Zhytomyr & High & High & High & High & High \\
\hline $\begin{array}{c}\text { Zakarpat- } \\
\text { tya }\end{array}$ & $\begin{array}{c}\text { Intensi- } \\
\text { fied }\end{array}$ & High & $\begin{array}{c}\text { Intensi- } \\
\text { fied }\end{array}$ & $\begin{array}{c}\text { Intensi- } \\
\text { fied }\end{array}$ & $\begin{array}{c}\text { Increa- } \\
\text { sed }\end{array}$ \\
\hline $\begin{array}{c}\text { Zapori- } \\
\text { zhya }\end{array}$ & Low & High & $\begin{array}{c}\text { Intensi- } \\
\text { fied }\end{array}$ & Low & $\begin{array}{c}\text { Increa- } \\
\text { sed }\end{array}$ \\
\hline \begin{tabular}{|c|} 
Ivano- \\
Frankivsk \\
\end{tabular} & High & High & High & High & High \\
\hline Kyiv & $\begin{array}{c}\text { Intensi- } \\
\text { fied }\end{array}$ & $\begin{array}{c}\text { Intensi- } \\
\text { fied }\end{array}$ & $\begin{array}{c}\text { Intensi- } \\
\text { fied }\end{array}$ & $\begin{array}{c}\text { Intensi- } \\
\text { fied }\end{array}$ & $\begin{array}{c}\text { Intensi- } \\
\text { fied }\end{array}$ \\
\hline
\end{tabular}

Continuation of Table 3

\begin{tabular}{|c|c|c|c|c|c|}
\hline Region & 2016 & 2017 & 2018 & 2019 & \begin{tabular}{|c} 
General \\
conso- \\
lidated \\
indica- \\
tor
\end{tabular} \\
\hline Kirovograd & High & High & High & High & High \\
\hline Luhansk & High & High & High & High & High \\
\hline Lviv & $\begin{array}{c}\text { Intensi- } \\
\text { fied }\end{array}$ & $\begin{array}{c}\text { Intensi- } \\
\text { fied }\end{array}$ & $\begin{array}{c}\text { Intensi- } \\
\text { fied }\end{array}$ & $\begin{array}{c}\text { Intensi- } \\
\text { fied }\end{array}$ & $\begin{array}{c}\text { Intensi- } \\
\text { fied }\end{array}$ \\
\hline Mykolaiv & $\begin{array}{c}\text { Intensi- } \\
\text { fied }\end{array}$ & High & $\begin{array}{c}\text { Intensi- } \\
\text { fied }\end{array}$ & High & High \\
\hline Odessa & $\begin{array}{c}\text { Intensi- } \\
\text { fied }\end{array}$ & High & $\begin{array}{c}\text { Intensi- } \\
\text { fied }\end{array}$ & $\begin{array}{l}\text { Intensi- } \\
\text { fied }\end{array}$ & $\begin{array}{c}\text { Intensi- } \\
\text { fied }\end{array}$ \\
\hline Poltava & $\begin{array}{c}\text { Intensi- } \\
\text { fied }\end{array}$ & High & $\begin{array}{c}\text { Intensi- } \\
\text { fied } \\
\end{array}$ & High & High \\
\hline Rivne & High & High & High & High & High \\
\hline Sumy & High & High & High & High & High \\
\hline Ternopil & High & High & High & High & High \\
\hline Kharkiv & $\begin{array}{c}\text { Intensi- } \\
\text { fied }\end{array}$ & $\begin{array}{c}\text { Intensi- } \\
\text { fied } \\
\end{array}$ & $\begin{array}{c}\text { Intensi- } \\
\text { fied } \\
\end{array}$ & $\begin{array}{c}\text { Intensi- } \\
\text { fied } \\
\end{array}$ & $\begin{array}{c}\text { Intensi- } \\
\text { fied }\end{array}$ \\
\hline Kherson & High & High & High & High & High \\
\hline $\begin{array}{c}\text { Khmelnyt- } \\
\text { skyi }\end{array}$ & High & High & High & High & High \\
\hline Cherkasy & High & High & High & High & High \\
\hline Chernivtsi & High & High & High & High & High \\
\hline Chernihiv & High & High & High & High & High \\
\hline
\end{tabular}

The high quality of the obtained classification is confirmed by the descriptive statistics shown on Figure 9 for 2016. Similar statistics were obtained for other years and also confirm the quality of the results.

\begin{tabular}{|c|c|c|c|c|c|c|}
\hline \multirow[b]{2}{*}{ Variable } & \multicolumn{6}{|c|}{ Analysis of Variance (Initial data 2016) } \\
\hline & $\begin{array}{c}\text { Between } \\
\text { SS }\end{array}$ & $\mathrm{df}$ & $\begin{array}{c}\text { Within } \\
\text { SS }\end{array}$ & df & $\mathrm{F}$ & $\begin{array}{c}\text { signif. } \\
p\end{array}$ \\
\hline GRP & $3,779001 \mathrm{E}+10$ & 2 & $2,806015 \mathrm{E}+10$ & 21 & 14,14087 & 0,000129 \\
\hline Unemployment & $7,274911 \mathrm{E}+03$ & 2 & $3,494719 \mathrm{E}+03$ & 21 & 21,85771 & 0,000007 \\
\hline Salary & $2,939246 E+06$ & 2 & $3,640264 \mathrm{E}+06$ & 21 & 8,47798 & 0,001999 \\
\hline Salary debts & $6,666879 \mathrm{E}+04$ & 2 & $2,689885 E+05$ & 21 & 2.60243 & 0,097790 \\
\hline Volume Industr & $8,989373 \mathrm{E}+10$ & 2 & $3,429795 \mathrm{E}+10$ & 21 & 27,52014 & 0,000001 \\
\hline Volume Retail & $5,306045 \mathrm{E}+09$ & 2 & $9,210588 \mathrm{E}+09$ & 21 & 6,04885 & 0,008422 \\
\hline Capital investments & $7,358755 \mathrm{E}+08$ & 2 & $8,470582 \mathrm{E}+08$ & 21 & 9,12180 & 0,001408 \\
\hline Cargo turnover & $8,586178 \mathrm{E}+07$ & 2 & $4,683572 E+09$ & 21 & 0,19249 & 0,826340 \\
\hline Passengers & $9,301757 E+06$ & 2 & $5,292718 \mathrm{E}+07$ & 21 & 1,84534 & 0,182687 \\
\hline Export & $2,713051 \mathrm{E}+13$ & 2 & $9,893583 E+12$ & 21 & 28,79344 & 0,000001 \\
\hline Import & $1,016460 E+13$ & 2 & $6,592575 \mathrm{E}+12$ & 21 & 16,18917 & 0,000056 \\
\hline Saldo & $1,229153 \mathrm{E}+13$ & 2 & $2,807015 \mathrm{E}+12$ & 21 & 45,97804 & 0,000000 \\
\hline Enterprises QTY & $3,258388 \mathrm{E}+08$ & 2 & $5,500332 \mathrm{E}+08$ & 21 & 6,22018 & 0,007559 \\
\hline Debts for Communal services & $1,225970 E+13$ & 2 & $2,780819 E+12$ & 21 & 46,29097 & 0,000000 \\
\hline Subsidies & $3,291820 E+10$ & 2 & $1,386078 \mathrm{E}+11$ & 21 & 2,49366 & 0,106735 \\
\hline Arrived, QTY & $5,010995 \mathrm{E}+08$ & 2 & $7,703228 \mathrm{E}+08$ & 21 & 6,83031 & 0,005188 \\
\hline Departed, QTY & $2,014319 \mathrm{E}+08$ & 2 & $4,298151 \mathrm{E}+08$ & 21 & 4,92080 & 0,017675 \\
\hline Migration & $8.968210 \mathrm{E}+07$ & 2 & $1,290358 \mathrm{E}+08$ & 21 & 7,29768 & 0,003923 \\
\hline
\end{tabular}

Fig. 9. Classification of regions by the data of 2016

Source: built by the authors

As can be seen from table 3, for the period from 2016 to 2019 there are quantitative and qualitative changes in the structure of the obtained classes (Table 4). 
Table 4 - The share of regions of each class by year

\begin{tabular}{|c|c|c|c|c|}
\hline \multirow{2}{*}{ Class } & \multicolumn{4}{|c|}{ Share, \% } \\
\cline { 2 - 5 } & 2016 & 2017 & 2018 & 2019 \\
\hline $\begin{array}{c}\text { Intensified } \\
\text { level of } \\
\text { social } \\
\text { tension }\end{array}$ & 29.2 & 16.7 & 33.3 & 20.8 \\
\hline $\begin{array}{c}\text { Low level } \\
\text { of social } \\
\text { tension }\end{array}$ & 12.5 & 8.3 & 8.3 & 12.5 \\
\hline $\begin{array}{c}\text { High level } \\
\text { of social } \\
\text { tension }\end{array}$ & 58.3 & 75 & 58.4 & 66.7 \\
\hline Total: & 100 & 100 & 100 & 100 \\
\hline
\end{tabular}

Source: compiled by the authors

Table 4 shows that the number of regions in the class with a high level of social tension is constantly growing and, unfortunately, the number of regions where the social sphere is more developed is decreasing. It should be noted that this situation is extremely dangerous, as it can lead not only to social but also economic and political crisis.

\section{Conclusion}

Thus, the classification of regions makes it possible to determine the list of preventive measures that can reduce the losses of both the state and regions associated with the containment of possible crises in the social sphere. In general, such measures that reduce the level of social tension caused by transformational changes in the social, economic and political spheres include:

- ensuring the effective use of regional potential on the basis of its real assessment, which will neutralize the weaknesses of socio-economic development and enhance the strengths;

- development and adoption of normative documents that would not only regulate regional policy, but also ensure its decentralization, which, in turn, will lead to effective socio-economic development of the regions and reduce existing disparities;

- determining by regions the long-term strategy of social and economic development, creation and realization of programs of regional development taking into account possibilities of each region;

- restructuring of regions and creating conditions for the location of production in economically backward regions, which will ensure sustainable development;
- development and practical implementation of a system of regional incentives that will create conditions for fuller use of the region's resources to increase the efficiency of its activities;

- increase of business and innovation activity, based on the interaction of local governments, industrial enterprises and economically active population, which will contribute to the development of the region's infrastructure, the market of goods and securities;

- increasing the investment attractiveness of the region, which will promote the introduction of innovative technologies and methods of solving socio-economic problems of regional development;

- ensuring social consolidation in order to minimize the social consequences of the restructuring of the region's economy;

- strengthening the regional consciousness of the population, which will allow to realize its potential and ensure the participation of the territorial community in the management of regional development.

It should be noted that the above list should take into account the specifics of the region that is part of each class.

\section{References:}

[1] Andrenko O., Mordovtsev S., Integral assessment of social tension of regions, Socioeconomic problems and the state, Vol. 2 (13), 2015, pp. 161-168.

[2] Baranova G.V., Analysis and forecasting of social tension in the regions of the Russian Federation, Labor and social relations, No. 5, 2007, pp. 112-118.

[3] Belay V., Research of social tension as a prerequisite for the emergence of crisis phenomena, Theory and practice of public administration, Vol. 3 (38), 2012, pp. 27-34.

[4] Voytovych A.D., Clustering of regions by the level of socio-economic development, Bulletin of Khmelnytsky National University, Vol. 1, No. 4, 2010, pp. 248-252.

[5] Golovenko V.A., The level of social tension and the potential of social protest in society: Possibilities of sociological research and forecasting, Ukrainian Society: Sociology. Policy. Economy. Pedagogy, No. 5-6, 2007, pp. 137-152.

[6] Guryanova L.S., SAR-models of the mechanism of assessment, analysis and forecasting of regional development, Business Inform, No. 6, 2015, pp. 60-66. 
[7] Janssen L., Kullberg M-L., Verkuil B, van Zwieten N, Wever M., van Houtum L., et al., Does the COVID-19 pandemic impact parents' and adolescents' well-being? An EMA-study on daily affect and parenting, PLoS ONE 15 (10): e0240962, 2020. https://doi.org/10.1371/ journal.pone.0240962

[8] State Statistics Service of Ukraine [Electronic resource]. Access mode: http://www.ukrstat.gov.ua

[9] Karamushka L.M., Social tension in the organization: the essence, approaches to the study, the main types, Actual problems of psychology: coll. Science. Proceedings of the GS Institute of Psychology Kostyuk NAPS of Ukraine, Volume I (45): Organizational Psychology. Economic psychology. Social Psychology, 2016, pp. 3-11.

[10] Klebanova T.S., Guryanova L.S., Trunova T.N., Smirnova A.Y., Assessment and analysis of uneven development of the regions of Ukraine, Actual problems of econom, No. 8 (98), 2009, pp. 162-166.

[11] Klebanova T.S., Guryanova L.S., Shevchenko I.K., Model basis of the early warning and localization of crises in economic systems of territories, Actual problems of economics, No. 3 (153), 2014, pp. 201-211.

[12] Mandel I.D.. Cluster analysis, Finance and Statistics, 1988, $176 \mathrm{p}$.

[13] Marinovic M.M., Glaría A., Marinovic D., Neurophenomenology of Social Tension: A Theoretical Framework for Modelling Prospective Scenarios, Proceedings of SAI Intelligent Systems Conference (IntelliSys), Lecture Notes in Networks and Systems, vol 15. Springer, Cham, 2016, https://doi.org/10.1007/978-3-319-56994-9 17

[14] Tkachenko O.M., Bilichenko N.O., GriyoTukalo O.F., Dzis O.V., Clustering method based on sequential start of k-means with calculation of distances to active centroids, Registration, storage and data processing, Vol. 14, No. 1, 2012, pp. 25-34.
[15] Rudachenko O.O., Klebanova T.S., Modern approaches to the analysis of social tension, Scientific Bulletin of Uzhhorod National University. Series "International Economic Relations and the World Economy", No. 30 (2), 2020, pp. 140-144.

[16] Rudachenko O.O., Formation of the main directions for reducing the social tension of the country, Scientific and economic journal "Intellect XXI", Issue 1, 2020, pp. 71-75.

[17] Slyusarevsky M., Social tension: a theoretical model of necessary and sufficient indicators, Scientific studies in social and political psychology, No. 5 (8), 2002, pp. 24-34.

[18] Chagovets L.O., Chagovets V.V., Didenko A.S., Conceptual basis for assessing and forecasting the unevenness of socioeconomic development of regions, Instrumental means of modeling systems in the information economy, VSHEM - S. Kuznets KhNEU, 2019, pp. 281-302.

[19] Burton J., Conflict: Human20 Needs Theory, N.Y .: St. Martin's Press, 1990.

[20] Babenko V., Perevozova I., Kravchenko M., Krutko M., Babenko D., Modern processes of regional economic integration of Ukraine in the context of sustainable development, E3S Web Conf., 166 (2020) 12001, 2020. doi: https://doi.org/10.1051/e3sconf/202016612001

[21] Klebanova T.S., Guryanova L.S., Shevchenko I.K., Model basis of the early warning and localization of crises in economic systems of territories, Actual problems of economics, No. 3 (153), 2014, pp. 201-211.

[22] Xiaohua D., Systematic Risk Measurement Based on CoVaR Model, International Journal of Circuits, Systems and Signal Processing, Vol. 13, 2019, pp. 243-250.

[23] Ward J.H., Hierarchical grouping to optimize an objective function, Journal of the American Statistical Association, 1963, 236 p.

[24] Zlobina O.G., Shulga M.O., Bevzenko L.D. et al., Social tension in the crisis society: sociopsychological analysis, Kyiv: Institute of Sociology of the National Academy of Sciences of Ukraine, 2019, $291 \mathrm{p}$. 


\section{Contribution of individual authors to the creation of a scientific article (ghostwriting policy)}

Klebanova T.S. identified a list of preventive measures that can reduce the losses of the state related to containment of possible crises in the social sphere.

Rudachenko O. developed a methodical approach to the classification of regions according to the level of formation of social tension.

Gvozdytsky V. carried out the modelling of the classification of regions of Ukraine using Statistica application package.

Mozgovoy I. conducted a search and processing of statistical reports required for the study.

Guryanova L.S. provided a list of activities that should take into account the specifics of the region which is a part of each class.

\section{Creative Commons Attribution License 4.0 (Attribution 4.0 International, CC BY 4.0)}

This article is published under the terms of the Creative Commons Attribution License 4.0

https://creativecommons.org/licenses/by/4.0/deed.en_US 